\title{
Analisis Penggunaan Combine Harvester Terhadap Pendapatan Petani Dari Usahatani Padi Di Desa Lambunot Kecamatan Simpang Tiga Kabupaten Aceh Besar \\ (The Analysis Of The Use Of Combine Harvesters On Farmer's Income From Rice Farming In Lambunot Village, Simpang Tiga Subdistrict, Aceh Besar Regency)
}

\author{
Noufal Fadlul Rahman ${ }^{1}$, Sofyan ${ }^{1}$, Agustina Arida ${ }^{1 *}$ \\ ${ }^{1}$ Program Studi Agribisnis, Fakultas Pertanian, Universitas Syiah Kuala \\ *Corresponding author: agustinaarida@unsyiah.ac.id
}

\begin{abstract}
Abstrak. Padi merupakan salah satu komoditas sebagai bahan untuk mencukupi kebutuhan pokok masyarakat maupun sebagai sumber pendapatan petani. Desa Lambunot merupakan salah satu desa di Kecamatan Simpang Tiga Kabupaten Aceh Besar dimana dalam 2 tahun terakhir sudah beralih menggunakan mesin pemanen padi modern combine harvester dalam proses pemanenan padi. Adapun keuntungan dari penggunaan alat ini yaitu dapat mengurangi kehilangan hasil, mengurangi tenaga kerja dan alat-alat pertanian, serta waktu pemanenan menjadi lebih singkat, sehingga dianggap dapat meningkatkan pendapatan petani pengguna. Penelitian ini bertujuan untuk mengetahui perbandingan besar pendapatan serta untuk mengetahui komponen biaya terbesar selama satu kali musim tanam dalam usahatani padi petani pengguna mesin combine harvester dengan petani non-combine harvester di Desa Lambunot. Teknik analisis yang digunakan pada penelitian ini yaitu analisis pendapatan dan uji t (Independent sample T Test). Hasil penelitian menunjukkan bahwa rata-rata pendapatan bersih per $1 \mathrm{Ha}$ usahatani padi petani pengguna combine harvester lebih besar dibandingkan dengan pendapatan bersih usahatani padi petani non-combine harvester, yaitu Rp. 12.502 .572 berbanding Rp. 9.646.198. Pada hasil pengujian uji $\mathrm{t}$ juga menjelaskan bahwa terdapat perbedaan pendapatan bersih yang signifikan antara usahatani padi petani pengguna combine harvester dengan usahatani padi petani non-combine harvester. Kemudian komponen biaya terbesar pada usahatani padi petani combine harvester terdapat pada biaya pemanenan atau ongkos combine harvester dengan biaya sebesar Rp. 2.778 .718 atau 30,78 \% dari total biaya produksi, sedangkan komponen biaya terbesar pada usahatani padi petani non-combine harvester terdapat pada biaya atau ongkos tenaga kerja dengan biaya sebesar Rp. 3.246.344 atau 31,48 \% dari total biaya produksi. Dapat disimpulkan bahwa penggunaan mesin pemanen padi combine harvester sangat layak digunakan oleh petani kedepannya karena terbukti dapat memangkas biaya produksi serta menekan kehilangan hasil (losses) sehingga menambah pendapatan petani pengguna.
\end{abstract}

Kata kunci : Padi, combine harvester, power thresher, tenaga kerja, pendapatan.

\begin{abstract}
Rice is one of the commodities as an ingredient to meet the basic needs of the community and as a source of income for farmers. Lambunot Village is one of the villages in Simpang Tiga Subdistrict, Aceh Besar Regency which in the last 2 years has switched to using a modern rice harvester combine harvester in the rice harvesting process. The advantages of using this tool are that it can reduce yield loss, reduce labor and agricultural tools, and shorten harvesting time, so that it is considered to increase the income of user farmers. This study aims to determine the ratio of income and to determine the largest cost component during one growing season in rice farming farmers using combine harvester machines with non-combine harvester farmers in Lambunot Village. The analytical technique used in this research is income analysis and t-test (Independent sample T Test). The results showed that the average net income per 1 ha of rice farming using combine harvester farmers was greater than the net income of non-combine harvester farmers, which was Rp. 12,502,572 compared to Rp. 9,646,198. The results of the t-test test also explain that there is a significant difference in net income between rice farming farmers using combine harvesters and rice farming farmers using non-combine harvesters. Then the largest cost component in rice farming for combine harvester farmers is the cost of harvesting or combine harvester costs with a cost of Rp. $2,778,718$ or $30.78 \%$ of the total cost of production, while the largest cost component in non-combine harvester rice farming is the labor cost or cost of Rp. 3,246,344 or $31.48 \%$ of the total production cost. It can be concluded that the use of a combine harvester rice harvester is very feasible for farmers to use in the future because it is proven to be able to cut production costs and reduce losses so that it increases the income of user farmers.
\end{abstract}

Keywords : Rice, combine harvester, power thresher, labor, income. 


\section{PENDAHULUAN}

Padi merupakan salah satu komoditas yang memegang peranan cukup penting bagi perekonomian negara, yaitu sebagai bahan untuk mencukupi kebutuhan pokok masyarakat maupun sebagai sumber pendapatan petani. Oleh karena itu sektor pertanian harus terus ditingkatkan, sehingga menjadi sumber yang penting dalam pelaksanaan pembangunan. Tanaman padi merupakan tanaman yang di budidayakan dengan pola tanam dan musim yang serentak, hal ini membuat proses pemanenan padi dilakukan secara bersamaan dan membutuhkan tenaga kerja yang tidak sedikit, sedangkan waktu dari proses panen hingga pascapanen harus dilakukan secepat mungkin agar tidak merusak mutu dari padi itu sendiri. Sebenarnya ini dapat diatasi dengan pengadaan tenaga kerja yang banyak, namun ini akan memakan biaya yang besar, maka dari itu diperlukan alat bantu mekanis yang dapat menggantikan tenaga kerja tersebut namun tetap dapat mempercepat proses panen.

Combine harvester adalah mesin pemanen padi yang dapat memotong bulir tanaman yang berdiri, merontokkan, dan membersihkan gabah sambil berjalan dilapangan. Dengan demikian waktu pemanenan padi menjadi lebih singkat dibandingkan dengan menggunakan tenaga manusia (manual) serta tidak membutuhkan jumlah tenaga kerja manusia yang besar seperti pada pemanenan tradisional (Smith dalam Purba et al, 2015). Penggunaan mesin ini dapat menggantikan dan meniadakan alat-alat pengikat, pemotong, dan perontok pada kegiatan pemanenan padi tradisional. Adapun keuntungan dari penggunaan alat ini yaitu dapat mengurangi biaya pemanenan dan perontokan, waktu pemanenan menjadi lebih singkat, kebutuhan tenaga kerja berkurang, lahan dapat lebih cepat dibersihkan untuk kegiatan pengolahan lahan tanah kembali, jerami terdistribusi di atas tanah serta proses pemasaran dari produksi ataupun hasil panen dapat segera dilakukan, sehingga kehadiran mesin pemanen padi combine harvester dianggap mampu meningkatkan efisiensi panen. Penggunaan mesin combine harvester dapat menekan kehilangan hasil panen (loses) dengan persentase kehilangan hanya 2-4 \%, sedangkan pemanenan secara tradisional persentase kehilangan hasil panen sebesar 6-8 \% (Amare dan Endalew, 2016). Munculnya mesin pemanen padi ini tentu sangat berguna bagi para petani karena dapat memangkas waktu pemanenan dan memangkas biaya panen yang besar jika dilakukan dengan cara manual atau dengan menggunakan jasa buruh tani.

Desa Lambunot merupakan salah satu desa di Kecamatan Simpang Tiga, Desa Lambunot juga merupakan salah satu desa dengan luas lahan padi terbesar ke 3 di Kecamatan Simpang Tiga dengan luas total 60 hektar (Kecamatan Simpang Tiga Dalam Angka, 2019). Dalam 2 tahun terakhir proses pemanenan padi di Desa Lambunot sudah beralih menggunakan mesin pemanen padi modern yaitu combine harvester. Meskipun sudah 2 tahun mesin combine harvester sudah dioperasikan, namun proses pemanen padi di Desa Lambunot masih sangat variatif karena sebagian besar masyarakat petani masih belum menggunakan mesin combine harvester yaitu masih menggunakan cara manual dan mesin thresher pada saat proses pemanenan. Padahal jika kita mengacu pada keuntungan dan kelebihan dari mesin combine harvester maka akan dapat meningkatkan pendapatan petani penggunanya, sehingga perlu dikaji apakah benar dengan adanya combine harvester dapat meningkatkan pendapatan petani pengguna dan apakah ada perbedaan pendapatan antara petani non-combine harvester. Sehingga tujuan penelitian yaitu (1) Untuk mengetahui perbandingan besar pendapatan bersih pada usahatani padi petani pengguna mesin combine harvester dengan petani non-combine harvester di Desa Lambunot (2) Untuk mengetahui komponen biaya terbesar selama satu kali 
musim tanam dalam usahatani padi antara petani pengguna combine harvester dengan noncombine harvester.

\section{METODE PENELITIAN}

\section{Tempat Dan Waktu Penelitian}

Penelitian ini dilakukan di Desa Lambunot Kecamatan Simpang Tiga Kabupaten Aceh Besar Provinsi Aceh. Daerah penelitian ini ditentukan secara purposive atau disengaja, penentuan lokasi dikarenakan Desa Lambunot adalah Desa dengan usaha pertanian padi dan sudah menggunakan mesin pemanen padi combine harvester. Waktu penelitian ini dilakukan pada bulan Februari - Maret 2021.

\section{Objek Dan Ruang Lingkup Penelitian}

Objek penelitian ini terfokus kepada petani padi pengguna mesin combine harvester dan petani padi non-combine harvester dengan status lahan milik pribadi. Sedangkan ruang lingkup penelitian ini terbatas pada pendapatan petani dari usahatani padi serta besar komponen biaya selama satu kali musim tanam padi antara petani pengguna mesin combine harvester dengan petani non-combine harvester.

\section{Jenis Dan Sumber Data}

Jenis data yang digunakan dalam penelitian ini adalah data primer dan data sekunder. Data primer diperoleh dengan menggunakan teknik wawancara langsung kepada responden dengan menggunakan daftar pertanyaan (kuisioner) sebagai alat bantu dalam pengumpulan data, sedangkan data sekunder diperoleh dari Badan Pusat Statistik (PBS) dan instansiinstansi terkait.

\section{Populasi Dan Sampel}

Desa Lambunot adalah desa pertanian dengan usaha pertanian padi, usaha pertanian padi tidak hanya dijalankan oleh keluarga petani saja namun juga dijalankan oleh seluruh kalangan keluarga meskipun dengan latar belakang Pegawai Negeri Sipil dan lain sebagainya. Dari data terakhir menunjukkan bahwa jumlah seluruh keluarga di Desa Lambunot sejumlah 193 keluarga (Kecamatan Simpang Tiga Dalam Angka 2019).

Dalam pengambilan sampel, peneliti menggunakan sebanyak 39 sampel keluarga usahatani, penentuan jumlah sampel dengan menggunakan rumus Suparmoko (2003) :

$$
\mathrm{n}=\frac{N Z^{2} P(1-P)}{N D^{2}+Z^{2} P(1-P)}
$$

Keterangan :

$\mathrm{n} \quad=$ Jumlah sampel penelitian

$\mathrm{N}=$ Jumlah populasi penelitian

$\mathrm{Z}=$ Variabel normal standar $(1,64)$

$\mathrm{P}=$ Persentase variance ditetapkan $(0,05)$

$\mathrm{D}=$ Kesalahan maksimum yang dapat diterima $(0,10)$ 
Dari hasil pra-survei menunjukkan dari total 193 petani responden terdapat 82 petani responden yang telah menggunakan combine harvester dalam proses pemanenan padi, sedangkan sisanya yaitu 111 petani responden masih menggunakan cara manual atau noncombine harvester dalam proses pemanenan padi. Sehingga dalam perhitungan jumlah sampel didapatkan 19 sampel untuk responden petani pengguna combine harvester dan 20 sampel untuk responden petani non-combine harvester.

\section{Metode Analisis Data}

Penelitian ini adalah penelitian analisis kuantitatif. Analisis kuantitatif digunakan untuk mengetahui berapa besar pendapatan petani dari usaha tani padi pemakai mesin combine harvester dan pendapatan petani dari usaha tani padi non-combine harvester.

Untuk mengetahui besarnya pendapatan petani dari usaha tani padi di Desa lambunot, maka analisis data yang digunakan adalah analisis pendapatan. Untuk mengetahui total input (biaya) yang dikeluarkan petani selama satu musim tanam dapat ditentukan dengan menggunakan rumus sebagai berikut :

$$
\mathrm{TC}=\mathrm{FC}+\mathrm{VF}
$$

Keterangan :

$\mathrm{TC}=$ Biaya total satu kali musim tanam $($ Total cost $)(\mathrm{Rp})$

$\mathrm{FC}=$ Biaya tetap (Fixed cost $)(\mathrm{Rp})$

$\mathrm{VC}=$ Biaya variabel $($ Variable cost $)(\mathrm{Rp})$

Sedangkan untuk mengetahui total output (penerimaan) satu musim panen padi yang diterima petani dapat ditentukan dengan menggunakan rumus sebagai berikut :

$$
\mathbf{T R}=\mathbf{Y} \times \mathbf{P}
$$

Keterangan :

$\mathrm{TR}=$ Total penerimaan satu kali musim tanam padi $(\mathrm{Rp})$

$\mathrm{Y} \quad=$ Produksi padi satu kali musim tanam $(\mathrm{Kg})$

Py $\quad=$ Harga jual padi $(\mathrm{Rp})$

Sedangkan untuk mengetahui total pendapatan bersih petani per musim panen padi yang diterima petani dapat ditentukan dengan menggunakan rumus sebagai berikut :

$$
\pi=\mathbf{T R}-\mathbf{T}
$$

Keterangan :

$\pi \quad=$ Pendapatan bersih dari usahatani padi $(\mathrm{Rp})$

$\mathrm{TR}=$ Total penerimaan satu kali musim tanam (Rp)

$\mathrm{TC}=$ Biaya total satu kali musim tanam $(\mathrm{Rp})$

(Siadina et al, 2019)

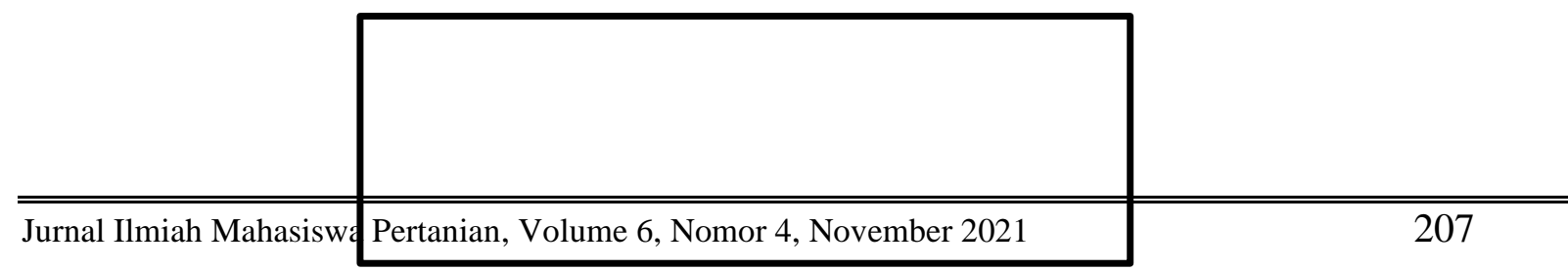




$$
t=\frac{\overline{x_{1}}-\overline{x_{2}}}{\sqrt{\frac{\left(n_{1}-1\right) s_{1}^{2}+\left(n_{2}-1\right) s_{2}^{2}}{n_{1}+n_{2}-2}\left(\frac{1}{n_{1}}+\frac{1}{n_{2}}\right)}}
$$

Keterangan :

$\overline{x_{1}} \quad=$ Rata-rata sampel 1

$\overline{x_{2}} \quad=$ Rata-rata sampel 2

$s_{1}^{2} \quad=$ Varian sampel 1

$s_{2}^{2} \quad=$ Varian sampel 2

$n_{1} \quad=$ Banyak subjek sampel 1

$n_{2} \quad=$ Banyak subjek sampel 2

Selanjutnya dilakukan uji beda atau disebut dengan uji t. Tujuan dari pengujian ini adalah untuk menguji perbedaan rata-rata antara 2 sampel yang tidak berpasangan atau dari 2 populasi yang berbeda (Independent Sample T Test), sehingga dari pengujian ini dapat diketahui apakah ada perbedaan yang signifikan antara pendapatan petani pengguna mesin pemanen padi combine harvester dengan petani non-combine harvester. Pengujian dilakukan dengan menggunakan Aplikasi SPSS 16.0 dengan tingkat signifikansi $5 \%$ dan interval kepercayaan sebesar $95 \%$. Adapun hipotesis yang akan diuji dalam penelitian ini yaitu sebagai berikut.

Hipotesis :

Ho = Pendapatan bersih dari usahatani padi petani pengguna mesin combine harvester lebih kecil dari petani non-combine harvester.

Ha = Pendapatan bersih dari usahatani padi petani pengguna mesin combine harvester lebih besar dari petani non-combine harvester.

Adapun kriteria atau dasar pengambilan keputusan dalam uji t ini yaitu sebagai berikut

1) Jika nilai signifikan / $P$ Value $>0,05$; maka Ho diterima.

2) Jika nilai signifikan / $P$ Value $<0,05$; maka Ho ditolak.

\section{HASIL DAN PEMBAHASAN}

\section{Gambaran Umum Desa Lambunot Kecamatan Simpang Tiga Kabupaten Aceh Besar}

Desa Lambunot merupakan salah satu desa dari 18 desa di Kecamatan Simpang Tiga, Kabupaten Aceh Besar, Provinsi Aceh. Desa Lambunot memiliki luas sebesar 4,11 $\mathrm{Km}^{2}$ atau $14,89 \%$ dari luas total Kecamatan Simpang Tiga. Desa Lambunot berjarak 2,2 Km dari Kecamatan Simpang Tiga dan $40 \mathrm{Km}$ dari pusat Kabupaten Aceh Besar. Desa Lambunot 
memiliki luas lahan sawah sebesar $60 \mathrm{Ha}$ dengan sistem irigasi teknis dengan sumber air utama dari waduk yang diberi nama atau sering disebut dengan sebutan "Mata Ie" yang terletak $\pm 1 \mathrm{~km}$ dari persawahan, kemudian lahan bukan sawah sebesar $425 \mathrm{Ha}$, dan lahan non pertanian sebesar 15 Ha. Mayoritas penduduk Desa Lambunot adalah $100 \%$ beragama Islam, jumlah penduduk Desa Lambunot berjumlah 842 jiwa.

Secara umum mata pencaharian masyarakat Desa Lambunot sangat beragam seperti petani, buruh tani, buruh bangunan, supir, ojek, pensiunan, pedagang, wirausaha, karyawan swasta, serta PNS/POLRI/TNI. Desa Lambunot adalah desa pertanian dengan usaha pertanian padi, usaha pertanian padi tidak hanya dijalankan oleh keluarga petani saja namun juga dijalankan oleh seluruh kalangan keluarga meskipun dengan latar belakang Pegawai Negeri Sipil dan lain sebagainya.

\section{Luas Lahan Petani}

Luas lahan dan status kepemilikan lahan sangat berpengaruh bagi pendapatan petani, semakin luas lahan usahatani maka semakin besar produksi padi sehingga pendapatan petani pun semakin besar. Sama halnya dengan status kepemilikan lahan, status kepemilikan lahan juga berpengaruh besar terhadap pendapatan petani, hal ini dikarenakan jika lahan tersebut adalah lahan milik pribadi maka seluruh hasil produksi adalah seutuhnya milik petani tersebut, berbeda jika lahan tersebut adalah lahan sewaan atau lahan milik orang lain maka hasil produksi haruslah dibagi sesuai kesepakatan bersama, sehingga status kepemilikan lahan berpengaruh terhadap besarnya pendapatan petani. Berdasarkan hasil penelitian tingkat luas lahan petani responden dapat dilihat pada tabel berikut.

Tabel 1. Jumlah petani responden berdasarkan luas lahan di Desa Lambunot Kecamatan Simpang Tiga Kabupaten Aceh Besar

\begin{tabular}{|c|c|c|c|c|}
\hline \multirow[b]{2}{*}{ No. } & \multirow[b]{2}{*}{ Luas Lahan (Ha) } & \multicolumn{2}{|c|}{ Petani } & \multirow[b]{2}{*}{ Jumlah } \\
\hline & & $\begin{array}{l}\text { Combine } \\
\text { Harvester }\end{array}$ & $\begin{array}{c}\text { Non-Combine } \\
\text { Harvester }\end{array}$ & \\
\hline 1. & 0,25 & 5 Petani & 7 Petani & 12 Petani \\
\hline 2. & 0,38 & 4 Petani & 3 Petani & 7 Petani \\
\hline 3. & 0,5 & 8 Petani & 7 Petani & 15 Petani \\
\hline 4. & 0,75 & 2 Petani & 2 Petani & 4 Petani \\
\hline 5. & 1 & 0 Petani & 1 Petani & 1 Petani \\
\hline \multicolumn{2}{|c|}{ Rata-Rata Luas Lahan } & $0,44 \mathrm{Ha}$ & $0,45 \mathrm{Ha}$ & \\
\hline
\end{tabular}

Berdasarkan Tabel 1 dapat diketahui bahwa rata-rata luas lahan petani padi combine harvester di Desa Lambunot yaitu sebesar 0,44 Ha, sedangkan rata-rata luas lahan petani padi non-combine harvester di Desa Lambunot yaitu sebesar 0,45 Ha. Berdasarkan data tersebut dapat dikatakan bahwa skala usahatani padi petani di Desa Lambunot termasuk kedalam skala kecil. Hal ini sejalan dengan pendapat Sajogyo (1977) yang mengelompokkan petani di Jawa ke dalam tiga kategori yaitu petani skala kecil dengan luas lahan usahatani <0,5 Ha, petani skala menengah dengan luas lahan usahatani 0,5-1,0 Ha, dan petani skala luas dengan luas lahan usahatani >1,0 Ha. Adapun status kepemilikan lahan petani padi combine harvester dan petani padi non-combine harvester di Desa Lambunot adalah milik sendiri atau milik pribadi. 


\section{Analisis Besar Pendapatan Usahatani Padi Petani Combine Harvester Dengan Petani Non-Combine Harvester di Desa Lambunot}

Pendapatan merupakan balas jasa dari kerjasama faktor-faktor produksi lahan, tenaga kerja, modal, dan pengelolaan. Secara harfiah pendapatan dapat didefinisikan sebagai sisa dari pengurangan nilai penerimaan yang diperoleh dengan biaya yang dikeluarkan. Untuk mengukur keberhasilan usahatani dapat dilakukan dengan melakukan analisis pendapatan usahatani, dengan melakukan analisis ini dapat diketahui gambaran usahatani saat ini sehingga dapat melakukan evaluasi untuk perencanaan kegiatan usahatani pada masa yang akan datang. Adapun yang dihitung dalam analisis pendapatan ini yaitu biaya produksi satu musim tanam padi, total penerimaan satu musim tanam padi, dan total pendapatan bersih satu musim tanam padi.

\section{Biaya Produksi Satu Musim Tanam Padi}

Biaya produksi atau biaya total adalah semua pengeluaran yang diperlukan untuk menghasilkan produksi. Biaya produksi dalam usahatani ini meliputi biaya variabel dan biaya tetap. Biaya variabel adalah biaya yang mempengaruhi besar kecilnya jumlah produksi yang dihasilkan oleh petani, yang ditentukan oleh tingkat penggunaan faktor-faktor produksi yang digunakan petani seperti benih, pupuk dan pestisida. Sejalan yang dikemukan ahli, biaya variabel atau Variable Cost (VC), yaitu biaya yang jumlah totalnya berubah-ubah sebanding dengan perubahan volume kegiatan, semakin tinggi volume kegiatan maka semakin tinggi pula total biaya variabel (Widjajanta dan Widyaningsih, 2009). Biaya tetap adalah biaya yang tidak mempengaruhi besar kecilnya jumlah produksi yang dihasilkan yang termasuk kedalam biaya ini yaitu seperti biaya alat-alat pertanian dan pemanenan. Sejalan yang dikemukakan oleh Widjajanta dan Widyaningsih (2009) biaya tetap atau Fixed Cost (FC), adalah biaya yang dalam periode waktu tertentu jumlahnya tetap, tidak bergantung pada jumlah produk yang dihasilkan.

Untuk mengetahui besarnya biaya produksi yang dikeluarkan petani baik yang menggunakan combine harvester maupun non-combine harvester di Desa Lambunot Kecamatan Simpang Tiga Kabupaten Aceh Besar dapat dilihat pada tabel berikut ini.

Tabel 2. Total rata-rata biaya produksi per $1 \mathrm{Ha}$ usahatani padi petani di Desa Lambunot Kecamatan Simpang Tiga Kabupaten Aceh Besar

\begin{tabular}{|c|c|c|c|}
\hline \multirow[b]{2}{*}{ No. } & \multirow[b]{2}{*}{ Uraian } & \multicolumn{2}{|c|}{ Total Biaya } \\
\hline & & $\begin{array}{l}\text { Combine } \\
\text { Harvester }\end{array}$ & $\begin{array}{c}\text { Non-Combine } \\
\text { Harvester }\end{array}$ \\
\hline \multirow[t]{5}{*}{1.} & Biaya Variabel (Variable Cost) & & \\
\hline & a) Benih & Rp. 430.024 & Rp. 460.912 \\
\hline & b) Pupuk & Rp. 1.379 .806 & Rp. 1.378 .512 \\
\hline & c) Pestisida & Rp. 260.944 & Rp. 301.236 \\
\hline & d) Tenaga kerja & Rp. 1.989 .116 & Rp. 3.246.344 \\
\hline \multicolumn{2}{|r|}{ Jumlah } & Rp. 4.059.914 & Rp. 5.405.004 \\
\hline 2. & Biaya Tetap (Fixed Cost) & & \\
\hline
\end{tabular}




\begin{tabular}{|c|c|c|}
\hline a) Pembajakan & Rp. 1.119.708 & Rp. 1.185 .600 \\
\hline b) Alat-alat pertanian & Rp. 1.071 .946 & Rp. 1.688.976 \\
\hline c) Biaya pemanenan & Rp. 2.778.718 & Rp. 2.032.620 \\
\hline Jumlah & Rp. 4.970.376 & Rp. 4.907.198 \\
\hline Total Biaya $(\mathrm{VC}+\mathrm{FC})$ & Rp. 9.030.290 & Rp. 10.312.202 \\
\hline $\begin{array}{l}\text { Nilai Selisih }(\mathrm{NCH}-\mathrm{CH}) \\
=\text { Rp. 10.312.202 }- \text { Rp. } 9.030 .290 \\
=\text { Rp. 1.281.912 }\end{array}$ & & \\
\hline
\end{tabular}

Sumber : Data kuisioner penelitian 2021

Berdasarkan Tabel 2 dapat diketahui bahwa rata-rata biaya produksi untuk biaya variabel yang dikeluarkan oleh petani combine harvester yaitu sebesar Rp. 4.059.914 dan untuk biaya tetap yaitu sebesar Rp. 4.970.376, sehingga total biaya produksi yang dikeluarkan petani combine harvester per 1 Ha yaitu sebesar Rp. 9.030.290. Sedangkan untuk petani noncombine harvester biaya produksi yang dikeluarkan jauh lebih besar dibandingkan dengan petani combine harvester dengan rata-rata biaya variabel yaitu sebesar Rp. 5.405.004 dan biaya tetap yaitu sebesar Rp. 4.907.198, sehingga total biaya produksi yang dikeluarkan petani non-combine harvester per 1 Ha yaitu sebesar Rp. 10.312.202. Adapun selisih biaya produksi per hektar yang dikeluarkan pada satu kali musim tanam antara petani combine harvester dengan non-combine harvester yaitu sebesar Rp. 1.281.912. Tingginya biaya produksi pada usahatani padi petani non-combine harvester dikarenakan besarnya biaya yang harus dikeluarkan petani pada biaya alat-alat pertanian dan biaya tenaga kerja, sehingga terdapat selisih biaya yang cukup besar.

Untuk mengetahui besarnya biaya penggunaan tenaga kerja pada usahatani padi petani combine harvester dan non-combine harvester dapat dilihat pada tabel berikut.

Tabel 3. Total rata-rata biaya penggunaan tenaga kerja per 1 Ha usahatani padi petani di Desa Lambunot Kecamatan Simpang Tiga Kabupaten Aceh Besar

\begin{tabular}{|c|c|c|c|}
\hline \multirow{2}{*}{ No. } & \multirow{2}{*}{ Tenaga Kerja } & \multicolumn{2}{|c|}{ Petani } \\
\hline & & Combine Harvester & Non-Combine Harvester \\
\hline 1. & Penanaman padi & Rp. 858.524 & Rp. 906.892 \\
\hline 2. & Pemotongan padi & Rp. 0 & Rp. 1.039 .903 \\
\hline 3. & Pengumpulan gabah & Rp. 0 & Rp. 327.690 \\
\hline 4. & Angkat padi & Rp. 695.284 & Rp. 755.743 \\
\hline 5. & Transportasi & Rp. 435.308 & Rp. 459.492 \\
\hline \multicolumn{2}{|c|}{ Total Biaya } & Rp. 1.989.116 & Rp. 3.489.720 \\
\hline \multicolumn{4}{|c|}{$\begin{array}{l}\text { Nilai Selisih }(\mathrm{NCH}-\mathrm{CH}) \\
=\text { Rp. 3.489.720 - Rp. 1.989.116 } \\
=\text { Rp. 1.500.604 }\end{array}$} \\
\hline
\end{tabular}


Berdasarkan Tabel 3 dapat diketahui bahwa terdapat perbedaan biaya total penggunaan tenaga kerja yang sangat besar antara petani pengguna combine harvester dengan petani non-combine harvester. Pada petani combine harvester biaya total penggunaan tenaga kerja yang dikeluarkan per $1 \mathrm{Ha}$ yaitu sebesar Rp. 1.989.116, sedangkan biaya total penggunaan tenaga kerja yang dikeluarkan oleh petani non-combine harvester hampir dua kali biaya total penggunaan tenaga kerja pada petani combine harvester yaitu sebesar Rp. 3.489.720 per $1 \mathrm{Ha}$. Rendahnya biaya penggunaan tenaga kerja pada petani combine harvester dikarenakan berkurangnya penggunaan tenaga kerja atau hilangnya penggunaaan tenaga kerja pada pemotongan dan pengumpulan gabah padi, berbeda dengan petani non-combine harvester yang masih menggunakan tenaga kerja pada pemotongan dan pengumpulan gabah padi, hal tersebutlah yang menyebabkan tingginya biaya penggunaan tenaga kerja pada usahatani padi petani non-combine harvester. Dari pernyataan tersebut dapat disimpulkan bahwa pengggunaan mesin combine harvester pada usahatani padi dapat menghemat biaya produksi salah satunya karena menghemat biaya penggunaan tenaga kerja. Hal ini sejalan dengan pendapat Smith dalam Purba et al (2015) combine harvester adalah mesin pemanen padi yang dapat memotong bulir tanaman yang berdiri, merontokkan, dan membersihkan gabah sambil berjalan dilapangan, dengan demikian waktu pemanenan padi menjadi lebih singkat dibandingkan dengan menggunakan tenaga manusia (manual) serta tidak membutuhkan jumlah tenaga kerja manusia yang besar seperti pada pemanenan tradisional.

\section{Total Penerimaan Satu Musim Tanam Padi}

Total penerimaan atau pendapatan kotor adalah hasil produksi padi selama satu musim tanam yang kemudian dikalikan dengan harga jual padi yang berlaku pada saat itu. Ini sejalan dengan pernyataan oleh Gustiyani (2004) yang menyatakan bahwa pendapatan kotor yaitu pendapatan yang diperoleh petani dalam usahatani selama satu tahun yang dapat diperhitungkan dari hasil penjualan atau pertukaran hasil produksi yang dinilai dalam rupiah berdasarkan harga persatuan berat pada saat pemungutan hasil.

Untuk mengetahui besarnya nilai penerimaan yang didapat petani baik yang menggunakan combine harvester maupun non-combine harvester di Desa Lambunot Kecamatan Simpang Tiga Kabupaten Aceh Besar dapat dilihat pada tabel berikut ini.

Tabel 4. Total rata-rata penerimaan per $1 \mathrm{Ha}$ usahatani padi petani di Desa Lambunot Kecamatan Simpang Tiga Kabupaten Aceh Besar

\begin{tabular}{|c|c|c|c|}
\hline \multirow{2}{*}{ No. } & \multirow{2}{*}{ Uraian } & \multicolumn{2}{|c|}{ Penerimaan Petani } \\
\hline & & Combine Harvester & Non-Combine Harvester \\
\hline 1. & Produksi $(\mathrm{Kg})$ & 5.127 & 4.752 \\
\hline 2. & Harga jual padi (Rp) & 4.200 & 4.200 \\
\hline \multicolumn{2}{|c|}{ Total Penerimaan } & Rp. 21.533.400 & Rp. 19.958.400 \\
\hline \multicolumn{4}{|c|}{$\begin{array}{l}\text { Selisih Produksi }(\mathrm{CH}-\mathrm{NCH}) \\
=5.127 \mathrm{Kg}-4.752 \mathrm{Kg} \\
=375 \mathrm{Kg}\end{array}$} \\
\hline \multicolumn{4}{|c|}{$\begin{array}{l}\text { Selisih Penerimaan }(\mathrm{CH}-\mathrm{NCH}) \\
=\text { Rp. } 21.533 .400-\text { Rp. } 19.958 .400 \\
=\text { Rp. } 1.575 .000\end{array}$} \\
\hline
\end{tabular}


Berdasarkan Tabel 4 dapat diketahui bahwa rata-rata produksi padi pada usahatani padi petani combine harvester per $1 \mathrm{Ha}$ yaitu sebanyak $5.127 \mathrm{Kg}$ dengan harga jual padi pada saat tersebut di Desa Lambunot sebesar Rp. 4.200/Kg, sehingga diperoleh penerimaan dari produksi padi sebesar Rp. 21.533.400. Sedangkan rata-rata produksi padi pada usahatani padi petani non-combine harvester per $1 \mathrm{Ha}$ yaitu sebanyak $4.752 \mathrm{Kg}$ dengan harga jual padi pada saat itu di Desa Lambunot sebesar Rp. 4.200/Kg, sehingga diperoleh penerimaan dari produksi padi sebesar Rp. 19.958.400. Dari tabel tersebut dapat disimpulkan bahwa produksi padi dan penerimaan dari usahatani padi petani combine harvester lebih besar dibandingkan petani non-combine harvester pada luas lahan yang sama dengan selisih perbedaan produksi sebesar $375 \mathrm{Kg}$ dan selisih penerimaan sebesar Rp. 1.575.000.

Besarnya perbedaan produksi padi pada usahatani padi antara petani combine harvester dengan petani non-combine harvester dikarenakan oleh faktor losses (kehilangan/susut hasil saat proses pemanenan). Dari hasil wawancara dengan petani bahwa proses pemanenan menggunakan mesin thresher membuat hasil panen atau produksi padi berkurang karena proses penggilingan yang terbuka membuat banyak padi yang tercecer dan hilang, berbeda dengan pemanenan menggunakan combine harvester yang proses pemisahan bulir padi dengan sistem tertutup dimana padi dipotong dan digiling pada saat yang bersamaan dan kemudian hasil panen langsung dapat dikarungkan sehingga tidak ada padi yang tercecer dan hilang. Selain itu kehilangan hasil juga disebabkan oleh proses pemotongan padi dan juga pada penumpukan gabah padi sebelum menuju proses perontokan dengan thresher, banyak bulir padi yang jatuh atau hilang pada proses ini sehingga menyebabkan berkurangnya produksi padi petani non-combine harvester bila dibandingkan dengan hasil produksi petani combine harvester.

Hal ini juga diungkapkan oleh Nasution (2019) dalam penelitiannya yang berjudul "Dampak Penggunaan Combine Harvester Terhadap Curahan Tenaga Kerja Dan Losses Pada Pemanenan Padi Sawah Desa Sidodadi Kecamatan Beringin Kabupaten Deli Serdang" yang menyatakan bahwa produksi usahatani padi sawah sebelum menggunakan combine harvester sebanyak 7.000,3 Kg per Ha sedangkan jumlah produksi sesudah menggunakan combine harvester yaitu sebanyak $7.067 \mathrm{Kg}$ per $\mathrm{Ha}$ dan total potensi produksi berdasarkan dari hasil penambahan produksi dan losses yaitu sebesar 7.125,3 $\mathrm{Kg}$ per Ha maka diperoleh losses sebelum menggunakan combine harvester sebesar $1,77 \%$ dan sesudah menggunakan combine harvester sebesar $0,82 \%$ maka diperoleh perbedaan lossing sebesar 0,95\%. Hilangnya hasil produksi disebabkan oleh proses pemotongan padi, penumpukkan padi sebelum proses penggilingan, dan pada proses pemasukkan padi kedalam mesin thresher.

Kemudian hal sama juga disampaikan oleh Amrullah dan Pullaila (2019) dalam jurnal yang berjudul "Dampak Penggunaan Combine Harvester Terhadap Kehilangan Hasil Panen Padi Di Provinsi Banten" yang menjelaskan bahwa penggunaan mesin combine harvester pada usahatani padi dapat menekan kehilangan hasil (losses) sebesar 200,39 kg per hektar atau sekitar 3,52 \% dari total hasil. Penggunaan mesin combine harvester dalam proses pemanenan padi dapat menekan kehilangan hasil (losses) saat kegiatan pemanenan sehingga hasil produksi yang diperoleh petani pun bertambah. Hasil penelitian ini sedikit lebih besar bila dibandingkan dengan perkiraan dari Balitbangtan (2015) yang menyebutkan bahwa penggunaan combine harvester bisa menekan kehilangan hasil saat panen kurang dari $2 \%$.

\section{Total Pendapatan Bersih Satu Musim Tanam Padi}


Total pendapatan bersih adalah nilai selisih antara total penerimaan (pendapatan kotor) dikurangi biaya produksi (biaya total) usahatani padi selama satu musim tanam padi. Gustiyani (2004) menjelaskan bahwa pendapatan bersih adalah penerimaan hasil penjualan dikurangi pembelian bahan, biaya transportasi, retribusi, dan biaya makan atau pendapatan total dimana total dari penerimaan (revenue) dikurangi total biaya (cost).

Untuk mengetahui besarnya pendapatan bersih yang didapat petani baik yang menggunakan combine harvester maupun non-combine harvester di Desa Lambunot Kecamatan Simpang Tiga Kabupaten Aceh Besar dapat dilihat pada tabel berikut ini.

Tabel 5. Total rata-rata pendapatan bersih per 1 Ha usahatani padi petani di Desa Lambunot Kecamatan Simpang Tiga Kabupaten Aceh Besar

\begin{tabular}{|c|c|c|c|c|}
\hline \multirow[b]{2}{*}{ No. } & \multirow[b]{2}{*}{ Petani } & \multicolumn{2}{|c|}{ Selisih ( - ) } & \multirow{2}{*}{$\begin{array}{l}\text { Pendapatan } \\
\text { Bersih (Rp) }\end{array}$} \\
\hline & & $\begin{array}{c}\text { Total Penerimaan } \\
\text { (Rp) }\end{array}$ & $\begin{array}{c}\text { Biaya Produksi } \\
\text { (Rp) }\end{array}$ & \\
\hline 1. & $\begin{array}{l}\text { Combine } \\
\text { Harvester }\end{array}$ & Rp. 21.533.400 & Rp. 9.030.290 & Rp. 12.502.572 \\
\hline 2. & $\begin{array}{l}\text { Non-combine } \\
\text { Harvester }\end{array}$ & Rp. 19.958.400 & Rp. 10.312.202 & Rp. 9.646.198 \\
\hline \multicolumn{5}{|c|}{$\begin{array}{l}\text { Selisih Pendapatan Bersih }(\mathrm{CH}-\mathrm{NCH}) \\
=\text { Rp. 12.502.572 - Rp. 9.646.198 } \\
=\text { Rp. 2.856.374 }\end{array}$} \\
\hline
\end{tabular}

Sumber : Data kuisioner penelitian 2021

Berdasarkan Tabel 5 dapat diketahui bahwa rata-rata pendapatan bersih dari usahatani padi yang diterima petani combine harvester lebih besar bila dibandingkan dengan rata-rata pendapatan bersih yang diterima petani non-combine harvester. Adapun rata-rata pendapatan bersih dari usahatani padi petani combine harvester per 1 Ha yaitu sebesar Rp. 12.502.572, sedangkan pendapatan bersih dari usahatani padi petani non-combine harvester per 1 Ha yaitu sebesar Rp. 9.646.198. Dari tabel diatas dapat disimpulkan bahwa pendapatan bersih usahatani padi petani combine harvester lebih besar dibandingkan dengan pendapatan bersih usahatani padi petani non-combine harvester pada luas lahan yang sama dengan selisih pendapatan sebesar Rp. 2.856.374.

Perbedaan pendapatan bersih antara usahatani padi petani combine harvester dengan petani non-combine harvester di Desa Lambunot Kecamatan Simpang Tiga Kabupaten Aceh Besar dikarenakan terdapat perbedaan biaya produksi dan penerimaan yang cukup besar, dimana terdapat selisih biaya produksi yang dikeluarkan pada usahatani padi petani combine harvester dengan usahatani padi petani non-combine harvester yakni sebesar Rp. 1.281.912, sedangkan selisih penerimaan antara usahatani padi petani combine harvester dengan usahatani padi non-combine harvester yakni sebesar Rp. 1.575.000.

Ini membuktikan bahwa usahatani padi di Desa Lambunot Kecamatan Simpang Tiga Kabupaten Aceh Besar dengan menggunakan alat pemanen padi combine harvester sangat layak untuk dijalankan dan dikembangkan kedepannya, hal ini dikarenakan dengan menggunakan mesin combine harvester dapat memangkas biaya produksi dan menekan kehilangan hasil (losses) saat kegiatan pemanenan sehingga akan berdampak pada peningkatan produksi padi dan pendapatan petani pengguna. 


\section{Uji Hipotesis}

Uji hipotesis dilakukan untuk menguji kebenaran akan hipotesis dalam penelitian ini. Uji hipotesis ini dilakukan dengan menggunakan analisis uji t. Tujuan dari uji t ini adalah untuk menguji perbedaan rata-rata antara 2 sampel yang tidak berpasangan atau dari 2 populasi yang berbeda (Independent Sample $T$ Test), sehingga dari pengujian ini dapat diketahui apakah ada perbedaan yang signifikan antara pendapatan petani pengguna mesin pemanen padi combine harvester dengan petani non-combine harvester. Pengujian dilakukan dengan menggunakan Aplikasi SPSS 16.0 dengan tingkat signifikansi $5 \%$ dan interval kepercayaan sebesar $95 \%$. Adapun hipotesis yang akan diuji dalam penelitian ini yaitu sebagai berikut.

Hipotesis :

Ho $=$ Pendapatan bersih dari usahatani padi petani pengguna mesin combine harvester lebih kecil dari petani non-combine harvester.

$\mathrm{Ha}=$ Pendapatan bersih dari usahatani padi petani pengguna mesin combine harvester lebih besar dari petani non-combine harvester.

Adapun kriteria atau dasar pengambilan keputusan dalam uji t ini yaitu sebagai berikut

1) Jika nilai signifikan / $P$ Value $>0,05$; maka Ho diterima.

2) Jika nilai signifikan / $P$ Value $<0,05$; maka Ho ditolak.

Berikut adalah hasil dari uji $\mathrm{t}$ (Independent Sample T Test) menggunakan aplikasi SPSS 16.0 .

Tabel 6. Hasil uji t (Independent Sample T Test) perbedaan pendapatan bersih usahatani padi petani combine harvester dengan petani non-combine harvester

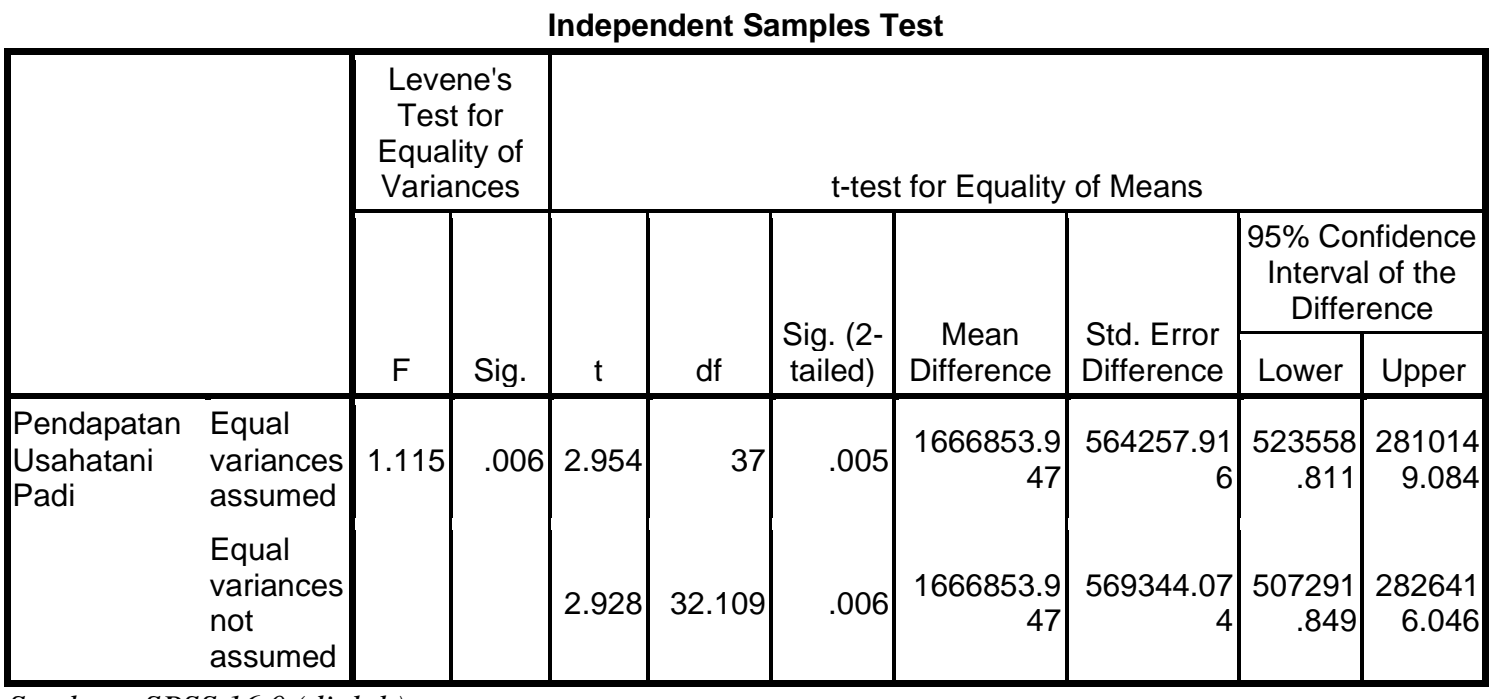

Sumber : SPSS 16.0 (diolah)

Berdasarkan Tabel 6 yaitu hasil dari uji t dapat dilihat yaitu pada tabel sig. (2 tailled) menunjukkan nilai signifikan sebesar 0,005 ini berarti bahwa nilai signifikan / $\mathrm{P}$ value lebih kecil dibandingkan 0,05 $(0,005<0,05)$ maka Ho ditolak dan terima Ha sehingga kesimpulan yang dapat ditarik adalah terdapat perbedaan pendapatan bersih yang signifikan yaitu pendapatan bersih dari usahatani padi petani pengguna mesin combine harvester lebih besar 
dari pendapatan bersih usahatani padi petani non-combine harvester di Desa Lambunot Kecamatan Simpang Tiga Kabupaten Aceh Besar.

Penggunaan mesin pemanen padi combine harvester terbukti dapat meningkatkan produksi padi petani pengguna karena dapat menekan kehilangan hasil (losses) serta dapat memangkas biaya produksi petani pengguna sehingga berpengaruh nyata pada peningkatan pendapatan petani pengguna, bisa disimpulkan bahwa penggunaan mesin combine harvester sangat layak digunakan oleh petani pada saat ini dan juga kedepannya.

\section{Komponen Biaya Terbesar Usahatani Padi Petani Combine Harvester Dengan Non- Combine Harvester}

Komponen biaya produksi padi merupakan semua faktor yang mempengaruhi banyaknya biaya dalam memproduksi padi dalam satu musim tanam. Berikut adalah komponen biaya terbesar usahatani padi petani combine harvester dengan non-combine harvester di Desa Lambunot Kecamatan Simpang Tiga Kabupaten Aceh Besar.

Tabel 7. Komponen biaya terbesar usahatani padi petani combine harvester dengan noncombine harvester per $1 \mathrm{Ha}$ di Desa Lambunot Kecamatan Simpang Tiga Kabupaten Aceh Besar

\begin{tabular}{|c|c|c|c|c|c|}
\hline \multirow{2}{*}{ No. } & \multirow{2}{*}{ Komponen Biaya } & \multicolumn{2}{|c|}{ Petani Combine Harvester } & \multicolumn{2}{|c|}{$\begin{array}{c}\text { Petani Non-Combine } \\
\text { Harvester }\end{array}$} \\
\hline & & $\overline{\text { Nominal (Rp) }}$ & $\begin{array}{c}\text { Persentase } \\
(\%)\end{array}$ & Nominal (Rp) & $\begin{array}{c}\text { Persentase } \\
(\%)\end{array}$ \\
\hline 1. & Benih & Rp. 430.024 & $4,76 \%$ & Rp. 460.912 & $4,47 \%$ \\
\hline 2. & Pupuk & Rp. 1.379 .806 & $15,28 \%$ & Rp. 1.378 .512 & $13,54 \%$ \\
\hline 3. & Pestisida & Rp. 260.944 & $2,89 \%$ & Rp. 301.236 & $2,92 \%$ \\
\hline 4. & Pembajakan & Rp. 1.119.708 & $12,40 \%$ & Rp. 1.185 .600 & $11,5 \%$ \\
\hline 5. & Alat-alat pertanian & Rp. 1.071 .946 & $11,87 \%$ & Rp. 1.688 .976 & $16,38 \%$ \\
\hline 6. & Combine harvester & Rp. 2.778 .718 & $30,78 \%$ & Rp. - & $0 \%$ \\
\hline 7. & Power thresher & Rp. - & $0 \%$ & Rp. 2.032 .620 & $19,71 \%$ \\
\hline 8. & Tenaga kerja & Rp. 1.989 .116 & $22,02 \%$ & Rp. 3.246.344 & $31,48 \%$ \\
\hline$\overline{\text { Total }}$ & & Rp. 9.030.290 & $100 \%$ & Rp. 10.312.202 & $100 \%$ \\
\hline
\end{tabular}

Sumber : Data kuisioner penelitian 2021

Berdasarkan Tabel 7 dapat diketahui bahwa komponen biaya terbesar pada usahatani padi petani combine harvester di Desa Lambunot Kecamatan Simpang Tiga terdapat pada biaya pemanenan atau ongkos combine harvester dengan biaya sebesar Rp. 2.778.718 atau 30,78 \% dari total biaya produksi. Sedangkan komponen biaya terbesar pada usahatani padi petani non-combine harvester di Desa Lambunot Kecamatan Simpang 
Tiga terdapat pada biaya penggunaan tenaga kerja dengan biaya sebesar Rp. 3.246.344 atau $31,48 \%$ dari total biaya produksi.

Dari hasil wawancara dengan petani padi di Desa Lambunot, beberapa petani mengatakan bahwa dalam beberapa tahun terakhir ini mereka hanya mendapatkan bantuan berupa benih padi dan pestisida, namun oleh kebanyakan petani menjual kembali benih tersebut ke toko-toko pertanian, hal tersebut dilakukan karena benih bantuan pemerintah tersebut tidak tumbuh dengan baik sehingga banyak petani yang mengalami kegagalan panen dan kerugian pada tahun-tahun sebelumnya.

Dari penjelasan diatas dapat di simpulkan bahwa seharusnya pemerintah lebih fokus dalam bantuan pengadaan mesin combine harvester terkhususnya di Desa Lambunot Kecamatan Simpang Tiga Kabupaten Aceh Besar dari pada bantuan dalam bentuk bibit atau pestisida seperti pada tahun sebelum-sebelumnya, karena dengan adanya bantuan pengadaan mesin combine harvester tentu ini akan sangat berdampak positif bagi para petani di Desa Lambunot terutama dalam hal peningkatan pendapatan dari usahatani padi mereka, seperti dalam penjelasan sebelumnya bahwa dengan menggunakan mesin combine harvester dapat memangkas biaya produksi dan menekan kehilangan hasil (losses) saat kegiatan pemanenan sehingga akan berdampak pada peningkatan produksi dan pendapatan dari usahatani padi petani pengguna. Dengan adanya bantuan berupa mesin combine harvester diharapkan juga para petani yang masih menggunakan jasa power thresher pada proses pasca panen dapat beralih ke pemanenan menggunakan mesin combine harvester sehingga pendapatan dari usahatani padi mereka pun juga meningkat.

\section{KESIMPULAN DAN SARAN}

\section{Kesimpulan}

Sesuai dengan hasil penelitian, adapun kesimpulan yang dapat diambil dari penelitian ini yaitu sebagai berikut :

a) Rata-rata pendapatan bersih usahatani padi yang diterima petani combine harvester lebih besar bila dibandingkan dengan pendapatan bersih yang diterima petani non-combine harvester di Desa Lambunot Kecamatan Simpang Tiga Kabupaten Aceh Besar per 1 Ha, adapun besar pendapatan bersih yang diperoleh petani combine harvester dari usahatani padi yaitu sebesar Rp. 12.502.572, sedangkan besar pendapatan bersih yang diperoleh petani non-combine harvester dari usahatani padi yaitu sebesar Rp. 9.646.198 dan dengan selisih pendapatan bersih sebesar Rp. 2.856.374. Pada hasil pengujian uji t (Independent Sample T Test) juga menjelaskan bahwa terdapat perbedaan pendapatan bersih yang signifikan antara pendapatan bersih usahatani padi petani combine harvester dengan pendapatan bersih usahatani padi petani non-combine harvester.

b) Komponen biaya terbesar pada usahatani padi petani combine harvester di Desa Lambunot Kecamatan Simpang Tiga Kabupaten Aceh Besar terdapat pada biaya atau ongkos combine harvester dengan biaya sebesar Rp. 2.778 .718 atau 30,78\% dari total biaya produksi, sedangkan komponen biaya terbesar pada usahatani padi petani noncombine harvester di Desa Lambunot Kecamatan Simpang Tiga terdapat pada biaya atau ongkos tenaga kerja dengan biaya sebesar Rp. 3.246.344 atau 31,48 \% dari total biaya produksi.

\section{Saran}


Sesuai dengan hasil penelitian, adapun saran yang dapat diambil dalam penelitian ini yaitu sebagai berikut :

a) Dengan adanya mesin canggih seperti combine harvester diharapkan dapat terus meningkatkan efisiensi pemanenan sehingga selalu berdampak positif terhadap pendapatan petani pengguna, diharapkan kepada petani pengguna combine harvester agar dapat terus memanfaatkan dan menggunakan jasa mesin combine harvester sebagaimana yang telah dijelaskan sebelumnya bahwa dengan menggunakan mesin pemanen padi combine harvester maka akan memangkas biaya produksi karena hilangnya penggunaan alat-alat pemanen padi dan penggunaan tenaga kerja yang banyak serta penggunaan mesin pemanen padi combine harvester dapat menekan kehilangan hasil (losses) pada saat proses pemanenan yang banyak sehingga akan berpengaruh pada peningkatan pendapatan dari usahatani padi, selanjutnya diharapkan kepada petani non-combine harvester kedepannya agar dapat beralih kepada pemanenan menggunakan mesin pemanen padi combine harvester sehingga dapat memangkas biaya produksi dan meningkatkan produksi seperti yang telah dijelaskan sebelumnya.

b) Diharapkan kepada pemerintah untuk lebih fokus dalam bantuan pengadaan mesin combine harvester terkhususnya di Desa Lambunot Kecamatan Simpang Tiga Kabupaten Aceh Besar dari pada bantuan pengadaan dalam bentuk bibit atau pestisida seperti pada tahun sebelum-sebelumnya, karena jika pemerintah mengadakan bantuan pengadaan mesin combine harvester tentu ini akan sangat berdampak positif bagi para petani di Desa Lambunot terutama bagi peningkatan pendapatan mereka.

\section{DAFTAR PUSTAKA}

Amare, Endalew. 2016. Agricultural Mechanization: Assessment Of Mechanization Impact Experiences On The Rural Population And The Implications For Ethiopian Smallholders. Engineering And Applied Sciences. 1(2): 39-48.

Amrullah, Pullaila. 2019. Dampak Penggunaan Combine Harvester Terhadap Kehilangan Hasil Panen Padi Di Provinsi Banten. Jurnal Agro Ekonomi, Vol. 37, No.2, Hal: 113-122.

BPS Aceh. 2019. Kecamatan Simpang Tiga Dalam Angka 2019. Badan Pusat Statistik Provinsi Aceh, Aceh.

Gustiyani, H. 2004. Analsis Pendapatan Usahatani Untuk Produk Pertanian. Salemba Empat, Jakarta.

Nasution, RH. 2019. Dampak Penggunaan Combine Harvester Terhadap Curahan Tenaga Kerja Dan Losses Pada Pemanenan Padi Sawah (Kasus : Desa Sidodadi, Kec Beringin, Kab. Deli Serdang). Skripsi. Program Studi Agribisnis Fakultas Pertanian Universitas Sumatera Utara, Medan.

Purba. 2015. Inovasi Teknologi Mesin Panen Mini Combine Harvester Mendukung Penanganan Panen dan Pascapanen Padi di Kalimantan Barat. Balai Pengkajian Teknologi Pertanian Kalimantan Barat.

Sajogyo, P. 1977. The Integration of Rural Women in National Deelopment in Indonesia. Home Economics and Social Programmes Service, Human Resources, Institutions and Agrarian Reform Division, Food and Agriculture Organization of The United Nations. 
Siadina, Kandatong, H., Astuti, I. 2019. Analisis Pendapatan Petani Padi Sawah Dengan Menggunakan Teknologi Alat Pasca Panen di Desa Sidorejo Kecamatan Wonomulyo Kabupaten Polewali Mandar. Agrofital : Jurnal Ilmu Pertanian, Vol. 4, No. 1, Hal : 30-37.

Suparmoko. 2003. Penilaian Ekonomi Sumberdaya Alam Dan Lingkungan (Konsep Dan Penilaian Sda). Lppem, Wacana Media.

Widjajanta, Widyaningsih. 2009. Mengasah Kemampuan Ekonomi. CV Citra Praya, Jakarta. 